\title{
FACTORS ASSOCIATED WITH HYPERTENSION AMONG ELDERLY IN PADANG BULAN, MEDAN, NORTH SUMATERA
}

\author{
Santa Ulina Apriani Situngkir, Namora Lumongga Lubis, \\ Fazidah Aguslina Siregar
}

Graduate Program in Public Health, Universitas Sumatera Utara

\begin{abstract}
Background: High blood pressure is a global public health problem. High blood pressure is called the "silent killer" because it often kills without warning signs or symptoms, and many people do not realize they have it. The world's population is ageing. Virtually every country in the world is experiencing growth in the number and proportion of older persons in their population. The incidence of hypertension is greatest among older adults. This study aimed to determine factors associated with hypertension incidence among elderly in Puskesmas Padang Bulan, Medan, North Sumatera.

Subjects and Method: This was a case control study conducted at Puskesmas (community health center) Padang Bulan, Medan, North Sumatera. A sample of 124 elderly persons was selected for this study, consisting of 62 persons with hypertension and 62 persons without hypertension. The dependent variable was hypertension. The independent variables were smoking, obesity, physical activity, fat diet, family history. Blood pressure was measured by sphygmomanometer. The other data were collected by questionnaire. The data were analyzed by a multiple logistic regression.

Results: Hypertension incidence increased with smoking ( $O R=5.57 ; p=0.007)$, obesity $(\mathrm{OR}=5.30 ; \mathrm{p}=0.001)$, lack of physical activity $(\mathrm{OR}=4.32 ; \mathrm{p}=0.001)$, high fat diet $(\mathrm{OR}=5.21 ; \mathrm{p}=0.023)$, and family history $(\mathrm{OR}=2.21 ; \mathrm{p}=0.001)$.

Conclusion: The risk of hypertension in elderly increases with smoking, obesity, lack of physical activity, high fat diet, and family history.
\end{abstract}

Keywords: hypertension, smoking, obesity, physical activity, fat diet, family history.

\section{Correspondence:}

Santa Ulina Apriani Situngkir. Graduate Program in Public Health, Universitas Sumatera Utara, Medan, North Sumatera. Email: situngkir_29@yahoo.com. Mobile: 081370430295 